Michelle R. Garfinkel is a senior economist at the Federal Reserve Bank of St. Louis. Scott Leitz provided research assistance.

\title{
The Economic Consequences of Reducing Military Spending
}

B summer, the easing of international tensions had reduced, for many, the urgency for the United States to continue building or even maintain its military strength. As support for allocating the nation's resources to defense weak. ened, people began to argue about the potential for a significant "peace dividend" available to the U.S. economy. ${ }^{1}$

How should the savings from reduced defense spending be put to use to enhance our nation's welfare? Many analysts, concerned primarily about the effects of large public deficits, have argued that the savings should be applied to reduce the government's need to borrow. ${ }^{2}$ Others have voiced concern that a reduction in defense expenditures will generate unemploy ment, at least temporarily, while resources are reallocated to productive activities in the civilian sector. ${ }^{3}$ Consequently, they have argued the initial savings should be used to ease this adjustment-perhaps by increasing expenditures on training programs. ${ }^{4}$ Many other policy recommendations have been made.

Although the current situation in the Middle East raises doubt that there will be any significant dividend in the near term, it does not detract from the relevance of such recommendations. Instead, it provides us with more time to evaluate the various options associated with future defense cuts.

In reviewing the economic implications of reduced military spending, this article examines some issues that have been overlooked by those in search of ways to use the "peace dividend." The article begins with a brief analysis of recent trends and the prospects for future cuts in military spending to see how large a dividend might be. Some simple economic principles are then employed to assess how the peace dividend, regardless of its actual magnitude, might be used to achieve diverse economic goals.
For example, see Pennar and Mandel (1989).

'See, for example, Schultze (1990).

3For example, see "Peace Dividend or Aecession?" (1990). Also see Pennar and Mandel (1989), who report the results of a study of the short- and long-term effects of reducing the defense budget by 5 percent a year in real terms from 1991 to 1994 and keeping it constant thereafter. Although this study predicts enhanced economic growth in the long run, it also predicts some short-term losses. Also see Ellis and Schine (1990), who report the results of a study indicating that as many as 1 million defense-related jobs for 20 percent of all jobs in defense-related activities) could be lost by 1995 . Although other analysts have argued that the empioyment losses could be insignificant (see, for example, Uchitelie (1990)), some defense contractors have already begun to cut production and employment.

4 See, for example, the bill proposed recently by Senator Pell (S.2097). 
Table 1

Trends in U.S. Defense Spending in the Past 50 Years

Total defense spendingt

\begin{tabular}{|c|c|c|c|}
\hline Deeade & Nominal & Real & share of GNP \\
\hline $1940 s$ & $\$ 35.8$ & $\$ 285,5$ & $18,3 \%$ \\
\hline $1950 \mathrm{~s}$ & 40.2 & 1870 & 101 \\
\hline $1960 s$ & 592 & 2164 & 8.4 \\
\hline $1970 s$ & 90.3 & 2000 & 5,8 \\
\hline $1080 s$ & 2303 & 2744 & 61 \\
\hline
\end{tabular}

aBilions of dollars averaged over the decade. The real figures are in 1989 dollars.

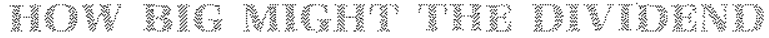 Yas}

To place the discussion of the economic implications of reduced defense needs into perspective, it is helpful to examine recent patterns of military spending. Table 1 shows three very different perspectives of U.S. military spending over the past 50 years. We can see that nominal military spending in the United States has grown considerably since the 1940s, rising from an average of $\$ 35.8$ billion per year during the decade that included World War II to an average of nearly $\$ 240$ billion per year during the 1980s. After adjusting for inflation, however, we see a somewhat different picture. Real military spending declined sharply immediately after the WWII decade; and, its pattern since the 1950 s has been more erratic, with its net rise by the 1980 s being considerably less dramatic than suggested by the nominal figures. Finally, as the table shows, military spending as a fraction of gross national product (GNP) has fallen markedly over the past five decades. Its share in the 1980 s was only onethird of that in the 1940s.

While military spending might now represent a fairly small proportion of GNP, it is still an important component of economic activity. Defense spending was $\$ 301.1$ billion in 1989 -more than $\$ 1200$ per person in the United States. ${ }^{5}$ This number suggests that there could be a considerable dividend from a large-scale disarmament.

Even without the Middle East crisis, however, the military spending cuts likely to have occurred in the near future would have been quite small relative to the whole economy. In a recent study, for example, the U.S. Congressional Budget Office (1990) estimated the effects of a proposal by the North Atlantic Treaty Organization (NATO) for limiting conventional forces in Europe. ${ }^{6}$ It found that the treaty would generate an annual savings of about $\$ 3$ billion in 1990 prices. Although $\$ 3$ billion seems large, it constitutes less than 1 percent of the total Defense Department's budget authority for fiscal year 1990 and less than .06 percent of 1989 GNP. This amounts to less than $\$ 13$ per year рег U.S. citizen.

This estimated savings from the prospective reduction in military spending pales in comparison to earlier U.S. disarmament efforts follow. ing wartime periods. ${ }^{7}$ After World War II, for example, defense spending fell by about $\$ 57.3$ billion from 1945 to 1946 , almost 27 percent of GNP in 1945. From 1953 to 1954, after the Korean $W$ ar, defense spending fell by $\$ 7.4$ billion, almost 2 percent of GNP in 1953 .

Forecasts of the actual size of future defense cuts, of course, are subject to much uncertainty. The budget proposed by President Bush in January 1990 for fiscal year 1991 called for reducing the defense budget by 2 percent after

intended to fight in the air and on the ground using cor:" ventional weapons.) It called for a 27 percent reduction in a selection of NATO weapons. Assuming an equally proportionate reduction by all NATO members, this requirement imples that the U.S. would have had to remove and destroy 600 tanks, 122 armored personnel carriers, 112 pieces of artillery, 189 helicopters and 105 aircrafts from Europe. Furthermore, about 30,000 U.S. troops would have had to be withdrawn from Europe and demobilized.

rAs noted below, however, the economic implications of a given reduction in military spending depend quantitatively on whether the reduction follows a war or occurs during a relatively peaceful period. the Warsaw Pact's ground capabilities in Europe and for reduction in their tactical aircraft capabilities that would leave an advantage for NATO. (Ground capability is measured by army units intended to fight on ground. Tactical aircraft capabilities are measured by fighters and bombers 
adjusting for inflation over the fiscal years 1991 to $1995 .{ }^{8}$ Others argued for defense spending cuts as much as 5 percent in real terms per year from fiscal years 1992 to 1994 , achieving an annual savings of about $\$ 60$ billion (in 1989 prices) starting in $1994 . .^{9}$ If cuts of this magnitude were implemented, the implied savings would constitute about 1.2 percent of GNP for the year 1989 , nearly $\$ 250$ per year on a per capita basis.

And the savings could be even larger. Indeed, on the day of the Iraqi invasion of Kuwait, President Bush announced that, although the invasion indicates a need to maintain a strong: military force, U.S. armed forces could be reduced by 25 percent over five years given the recent changes in Soviet-U.S. relations. ${ }^{10}$

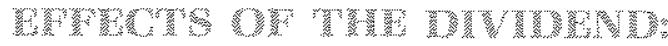

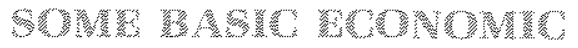

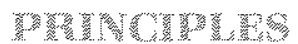

Generally speaking, the trade-off between competing uses of resources implies that a reduction in real military spending would provide a "dividend" in the form of increased real private and public consumption and investment opportunities m-that is, increased resources available for the production of consumption and investment goods. To quantify these increased opportunities over time, the annual peace dividend is defined here simply as the annual reduction in real military spending. ${ }^{11}$

Figure 1 illustrates this trade-off given the nation's resource and technology constraints by means of a hypothetical production possibility curve (PPC) for defense goods (national security) and nondefense goods (public and private investment and consumption). This curve depicts the maximum quantities of defense goods (M) and nondefense goods $(\mathrm{N})$ that can be produced simultaneously for given amounts of capital and labor inputs.
Figure 1

\section{PPC: Defense and Nondefense Goods}

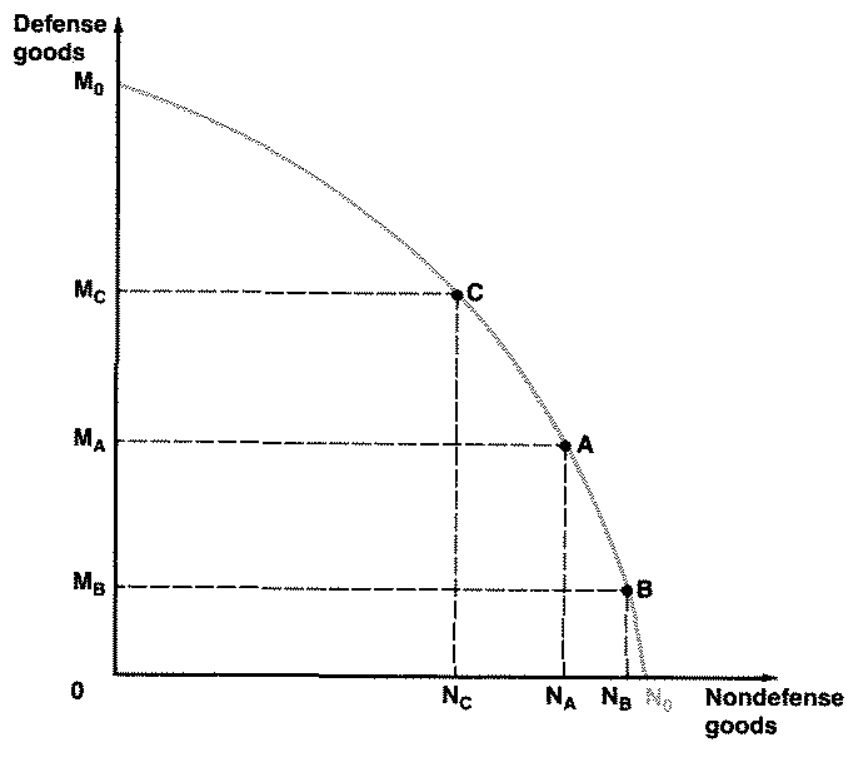

Assuming that resources are fully utilized, the economy is always operating on the frontier regardless of the level of military spending. If no resources were allocated to the production of defense goods, for example, the total output of nondefense goods would be shown as $\mathrm{N}_{0}$. Producing defense goods thus requires sacrificing the production of some goods for investment and consumption. The opportunity cost of providing a specific level of national security, for example, $M_{A}$, is the value of the lost production of nondefense goods, $N_{A}-N_{a}$. Conversely, if the economy were originally operating at point A, cutting military spending out entirely would imply increased production of nondefense goods, $\mathrm{N}_{\mathrm{A}}-\mathrm{N}_{\mathrm{a}}$. Thus, with a reduction in military spending (say $M_{B}-M_{A}$ ), the annual dividend would imply increased opportunities for the production of nondefense goods $\left(\mathrm{N}_{B}-\mathrm{N}_{A}\right)$. The shaded insert on pages 50 and 51 contains a discussion of the welfare implications of increased opportunities for investment and consumption afforded by a reduction in military spending.
8"Peace Dividend or Peace Recession?" (1990),

"The Peace Economy" (1989).

10Dowd (1990). Specifically, the Pentagon plan then called for cutting the armed forces by 500,000 troops from the current level of 2.1 million. But, without a clear resolution of the ongoing conflict in the Middle East, any reduction in military spending might seem optimistic. "11his definition envisions the dividend as a flow-i.e., as the term is normally understood. Thus, a permanent cut of $X$ dollars in real terms per year implies an $X$ dollar dividend each year indefinitely into the future. Using a present discounted value concept, these flows over time can be translated into a stock concept: $X / r$, where $r$ is the cons. tant real interest rate. 


\section{Will a Dividend Necessarily Enhance "Social Welfare?"}

Some interesting social welfare implications of lower miltary spending can be lllustrated within the simple $\mathrm{PPC}$ framework $\mathrm{Hgure} 2$ depiets the same PPC shown in figure 1 , add ed to the figure are wo indifference curves that show specific combinations of defense and nondefense goods which yield constant levels of national 'welfare' or atility " The curve labeled 4 indicates a higher level of wility than the one labeled $\mathrm{u}$, The shape of the indifference curves reflects the notion of diminishing soctal narginal ufility for exam. ple, the nation is less willing (must be given considerably nore nondefense goodst to decrease consumption of defense goods and consume nore nondefense good at point $Y$ compared with point?

At the point of tangetroy labeled $x$ ) be tween the indifference curve assoctated with ulitity $\mathrm{a}$ and the PPC, the nation's utility is maximized, given the avallable resource and technology constrainis, At his optimum level of consumption, the marginal uritity trade off

Figure 2

\section{Optimal Levels of Defense and Nondefense Goods}

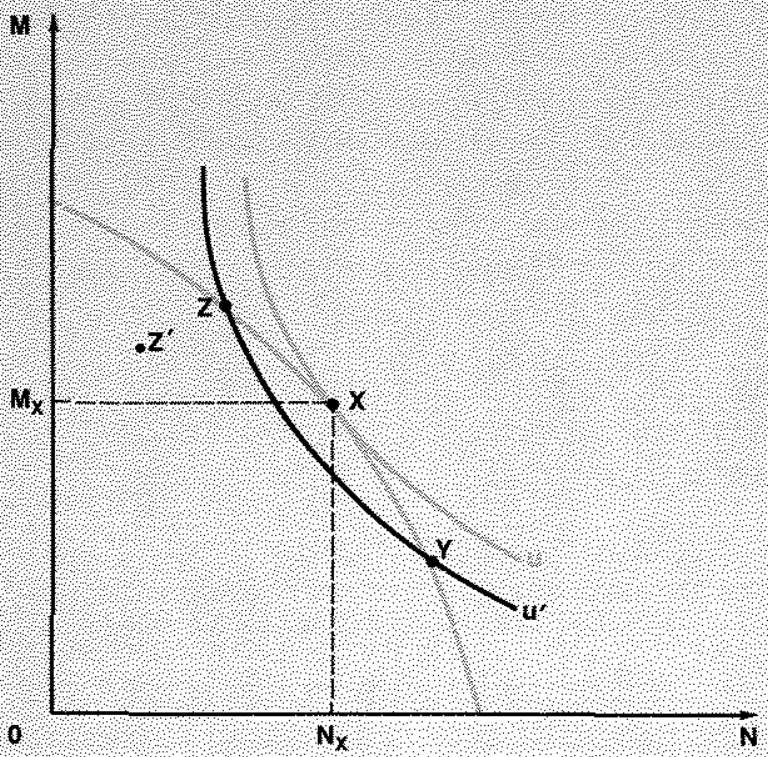

between defense and nondefense goods the slope of the indifference carve, a) equals the marginal rate of transformation between them (the slepe of the PPC), The optimal quantities of defense and nondefense goods are $\mathrm{M}_{\mathrm{x}}$ and $\mathrm{N}_{\mathrm{x}}$, respectively If preferences remain unchanged, a move to any other pro duetion combination on the $\mathrm{PPC}$ (or inside) would result in a lower level of national welfare, Thus, allhough a nove from point $\mathrm{X}$ to point $\mathrm{Y}$, for example, produces a positive dividend in the forn of horeased resources available 10 produce nondetense goods, it would actually reduce the nations welfare.

There are two seendrios, however, under whidh a decline in military spending could enhance velfare by creating increased con sumption and investment opportunities. Finst the original quantites of M and N could have been suboptinal if for example, the econ omy were operating at a point to the lett of

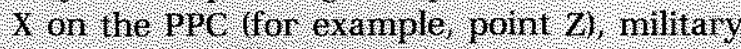
spending would be consrdered too high from

Figure 3

A Preference-Induced Change in the Optimal Levels of Detense and Nondefense Coods

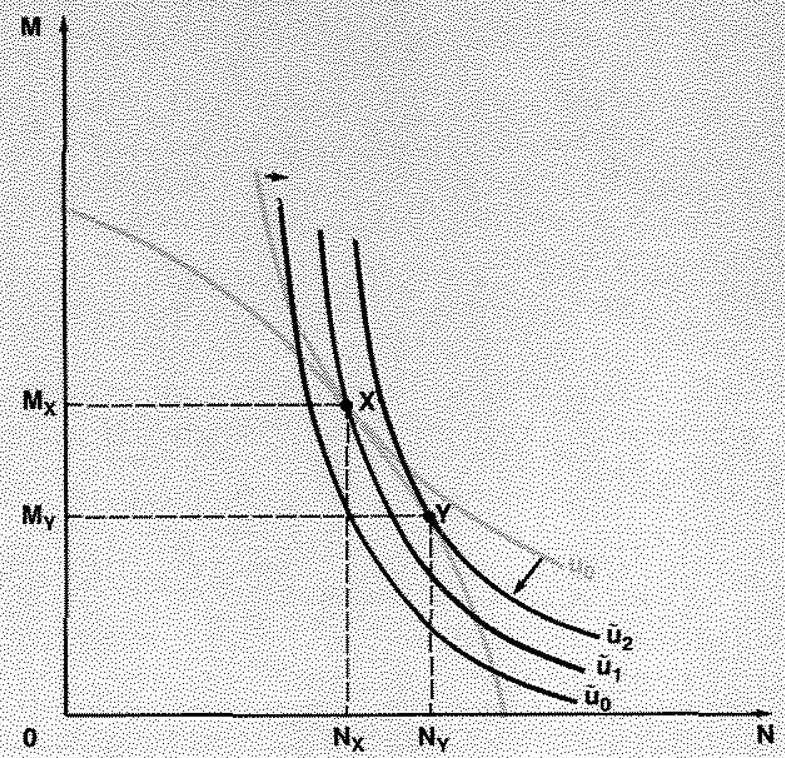


a social welfare point of view. Alternatively, the original point could have been inside the PPC above point $X$, such as $Z$ ' In this case, military spending is also too high and, more important the economy is operating below its potential output levels.

second, a cut in military spending could generate welfare gains if it were associated with an unanticipated decline in the severity of external threats. This seems to be the ex ample most relevant to the current situation involving U.S. Soviet relations. The reduced value of maintaining existing U.S military strength in the face of detente can be captured best by presuming there has been a

The concave shape of the PPC reflects diminishing marginal returns in productive transformation. That is, the amount of nondefense goods that must be sacrificed to produce one more defense good increases as $M$ increases. For example, in the figure, the move from $\mathrm{C}$ to $A$ and the move from $A$ to $B$ involve identical reductions in military spending. Starting at the point with a higher level of military spending $\left(M_{c}\right)$, however, that reduction in military spending implies greater additional production of nondefense goods than when starting at point $B$. (That is, $N_{A}-N_{C}>N_{B}-N_{A}$.) Hence, assuming resources are fully employed, a given reduction in the production of defense goods when the current level is low-for example, during peacetime-would imply smaller additions to consumption and investment opportunities than when the current level is high-for example, during wartime.

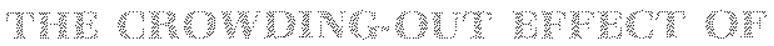

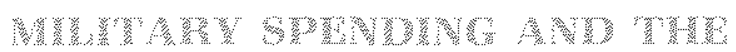

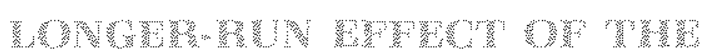

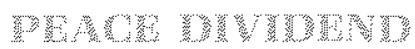

These allocative effects of the peace dividend can also have implications for the amount of resources available for production in general. general clockwise movement in the indifference curves. This movement is illustrated in figure 3 , where the new indifference. curves are labeled $\tilde{\mathrm{U}}$ If national security can be maintained with less military spending, a smaller quantity of $M$ with the same quantity of $\mathrm{N}\left(\mathrm{N}_{\times}\right)$produces the same utility level $\tilde{\mathbf{u}}_{0}=\mathrm{u}_{0}$. Further, the marginal value of increas ing $M$ relative to the cost of foregone consumption of $\mathrm{N}$ falls. The new welfare maximizing combination of $\mathrm{M}$ and $\mathrm{N}$ along the PPC is denoted by $\mathrm{Y}$, where $\mathrm{N}$ increases to $\mathrm{N}_{\mathrm{Y}}$ and $M$ decreases to $M_{Y}$. The net "welfare effect" of the dividend, $\mathrm{M}_{\mathrm{r}}-\mathrm{M}_{\mathrm{x}}$, would be reflected in the increase from $\overrightarrow{\mathrm{u}}$, $\mathrm{b} \overrightarrow{\mathrm{u}}$.

Specifically, any additional investment adds to the future resource base, thereby enhancing future output growth and investment and consumption opportunities. Hence, even if the decline in military spending were temporary, for example lasting only one year, its benefits in terms of increased productive capacity could be realized over many years. This longer-term effect can be modeled in the framework presented above by an outward shift of the PPC curve over time. ${ }^{12}$

Some analysts believe that, in recent decades, military spending has been excessive, reducing the residual supply of productive resources (that is, capital and labor) available for private and nondefense public investment and thereby weakening the economy. ${ }^{13}$ According to this "depletion" theory, the effects of higher levels of military spending are reflected in lower rates of investment and, consequently, lower rates of economic growth. Thus, the principal result of reduced military spending would be greater investment and economic growth.

Evidence on the "crowding-out" effect of military spending is based primarily on empirical analyses relating changes in military spending's share of GNP to the GNP shares of other broad categories of expenditures; typically, the studies focus on the effect on private investment's

\footnotetext{
12 Of course, one might argue that the level of military spending could positively influence the position of the PPC. Because military spending enhances a nation's ability to protect its resources, it might serve to increase the na. tion's future resource base by encouraging more investment.
}
13 See, for example, Dumas (1987), Melman (1988) and Du Boff (1989). In contrast, Weidenbaum (1990) argues that, as defense spending has fallen relative to GNP, the effects of such spending on the U.S. economy have become less significant.




\section{Table 2}

\section{Broad Categories of Real Expenditures as a Share of Real GNP1}

\begin{tabular}{|c|c|c|c|c|c|}
\hline Decade & 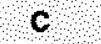 & 1 & $\mathbf{X}$ & Gnm & $\mathrm{Gm}$ \\
\hline $1940 s$ & $547 \%$ & $12,1 \%$ & $0.5 \%$ & $10,1 \%$ & $230 \%$ \\
\hline $1950 \mathrm{~s}$ & 584 & 165 & 011 & 118 & $13: 2$ \\
\hline $1960 \mathrm{~s}$ & 595 & 167 & -0.4 & 14.3 & 10,3 \\
\hline $1970 \mathrm{~s}$ & 622 & 172 & 00 & 149 & 62 \\
\hline $1980 s$ & 645 & 16.9 & 12 & 136 & 62 \\
\hline
\end{tabular}

Each category is converted into real terms using its implicit price deflator Separate price deflators were used for federal government spending and state and local government spending, but both defense and non-defense fedefal expen ditures were deflared by the same number:

share of GNP. ${ }^{14}$ Table 2 shows the trends in personal consumption expenditures (C), private domestic investment (I), nondefense public expenditures $\left(\mathrm{G}_{\mathrm{nm}}\right)$ on goods and services, defense expenditures $\left(G_{m}\right)$ and exports net of imports $(X)$ as shares of GNP over the past 50 years. To focus on the real effects of military spending, each broad category of spending is converted into real terms by dividing it by its own price deflator and by real GNP. ${ }^{15}$

As the table suggests, real military spending has crowded out all categories of real expendi- tures, not just real private domestic investment As real military spending's share fell from the 1940 s to the $1980 \mathrm{~s}$ by 16.8 percentage points, real consumption's share rose by nearly 10 percentage points. Real private investment's share and real nondefense public spending's share also rose over this period, though less dramatically. ${ }^{16}$ of course, in a broad sense, the substitu. tion observed between nondefense and defense public expenditures is consistent with the crowding-out notion; in this case, public investment on the nation's infrastructure-mat is, highways, airports, mass transit, water systems-was crowded out ${ }^{17}$

To be sure, the size of the peace dividend, as defined here, is independent of its allocation among the production of private and public consumption and investment goods. But its longer-term implications depend on that allocation. The best or "socially optimal" reallocation of resources among investment and current consumption depends on the nation's willingness to forego current consumption in order to invest and thereby enhance future consumption possibilities. The greater this willingness, the more likely the resources from a reduction in military spending will be devoted to additional investment rather than additional current consumption. The lower the nation's willingness to forego current consumption to enhance future consumption, the lower will be the proportion
${ }^{14}$ See Gold (1990) for an extensive survey of this evidence. Also see Adams and Gold (1987) and U.S. Congressional Budget Office (1983). It should be noted that identifying the degree to which military spending has resulted in lower expenditures on other goods and services and lower economic growth is difficult. The problem lies in determining how investment and other expenditures would have behaved if military spending had been different-in an extreme case, if it had been zero. Because reduced-form parameters relating defense expenditures to other expenditures would not be independent of the policy regime, estimates of these parameters might provide little information on how a permanent change in military spending (i.e., a policy regime change) would influence other expenditures. In addition, it is important to note that, if higher military expenditures result in higher levels of GNP, lower shares of investment, for example, need not imply a crowding-out effect of military spending.

${ }^{15} \mathrm{~A}$ comparison of tables 1 and 2 reveals that real military spending as a fraction of real GNP was higher than nominal military spending as a fraction of nominal GNP from the 1940 s to the 1970 s, but slightly lower during the $1980 \mathrm{~s}$. This divergence reflects the difference between the general price level of defense goods and that of all goods and services. The price level for defense goods, on average, was lower than the general price level between the 1940s and the 1970s, but higher during the 1980s. The focus on real military spending here is intended to emphasize the importance of its real allocative effects Failure to account for relative price movements masks these effects.

16Smith (1977) finds that the crowding-out effect of military's share of income on investment's share of income is nearly one to one for 14 OECD nations during the 1960 s. However, Boulding (1973), Edelstein (1989) and Aschauer (1989a) argue that this effect is not empirically relevant for the United States. Also see Browne (1989), who questions the validity of the argument that military research and development has crowded out civilian spending on research and development by "depleting" our nation's scientists and engineers. As is well-known, military R\&D has produced important innovations that have been applied successfully to production activities in the civilian sector; one commonly cited example is the computer. In addition, Browne argues that this crowding-oul effect on R\&D presumes that the supply of scientists and engineers is fixed. A greater demand for highly skilled labor, however, has inw fluenced its supply, although with the usual lag

${ }^{17 A s}$ an annual average of GNP, nef public infrastructure investment fell from approximately 2,3 percent in 1960-65 to about 0.8 percent in 1980-85 (Du Boff (1989), p. 7 , table 2). Aschauer (1989b) argues that the recent reduction in public capital, including infrastructure, might be responsi ble for the recent decline in productivity. 
of the savings that is allocated to investment. Thus, in contrast to the suggestion of the depletion theory briefly described above, the dividend from reduced military spending need not result in significantly greater rates of investment and economic growth. The extent to which the dividend will affect economic growth depends on how it is allocated among the production of investment and consumption goods.

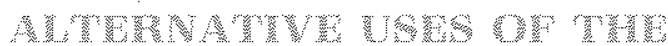

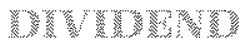

In recent decades, decreases in nominal military spending typically have been associated with increases in other public expenditures in nominal terms. Indeed, after falling to 19.5 percent in the 1950s from 25.1 percent during the 1940s, total public spending (federal plus state and local) on goods and services has remained roughly constant as a fraction of nominal GNP, around 20 percent; only the composition of those expenditures changed. Although there could be reasons why this pattern might persist in the upcoming decades, many analysts have questioned whether a continuation of this pattern is either likely or even desirable. Nevertheless, the basic question to be addressed should be couched in real terms: What should be done with the peace dividend?

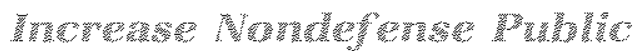

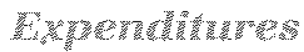

Some analysts have argued that leaving nondefense public expenditures alone and using the reduction in military spending to either decrease the deficit or lower taxes is not the best use of the peace dividend. Instead, many of them believe that at least part of the savings from arms reduction might best be used to increase nonmilitary government spending-specifically, to rebuild the nation's infrastructure. ${ }^{18}$ In terms of the economic framework above, this policy would shift out the PPC, in- creasing future production and consumption opportunities.

Others have argued that, unless the fall in military spending is somehow offset, resource utilization and, hence, economic activity will fall as well. ${ }^{19}$ In this view, which lies within the standard "Keynesian" paradigm, the government should use part (or all) of the savings to finance additional public expenditures, including noninfrastructure expenditures, such as welfare programs, to offset the negative effect of reduced military spending on aggregate demand.

This argument assumes that military spending in particular or public expenditures in general enhance social welfare not only by providing additional public goods, but by increasing employment and thereby stimulating the economy-that is, by inducing the use of idle resources. It implies that, without the increases in military spending or, more generally, public expenditures during the post-WWII period, the economy would have operated below its potential output capability (that is, inside its PPC).

Although there is evidence that a permanent decrease in military spending can produce a permanent decline in aggregate output ${ }^{20}$ the decline in output could be generated, in part, by a voluntary reduction in the supply of labor. In other words, this evidence does not necessarily imply that a permanent decline in military demand, without an increase in other public spending, would cause these productive resources to become involuntarily idle on a permanent basis.

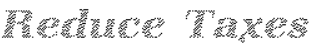

Some analysts would like us to consider an alternative policy that leaves other government expenditures unchanged and uses the dividend to reduce taxes. By increasing individuals' aftertax income, this policy might induce individuals to decrease their supply of labor, which would in turn decrease output without leaving labor resources involuntarily idle. ${ }^{2 *}$

\footnotetext{
18For example, see Du Boff (1989) and Melman (1988).

19For example, see Bolton (1966), especially pp. 37-41.

zoSee Barro (1981). In studying the output effects of government expenditures in the United States, he distinguishes permanent from temporary components of military spending. He finds that the effect of increases in temporary military spending (essentially wartime expenditures) on outpul was nearly one-for-one; increases in permanent mititary spending also increased output, but by less than the change in military spending.

21See Barro (1981) for a theoretic discussion of the effects of goverment expenditures on output. In support of this
}

line of reasoning, Dunne and Smith (1990) find that for the United States, military spending does not "cause" unemployment. Riddell (1988) argues, in a more Marxian spirit, that the government's apparent bias for military over non-military expenditures is driven by its objective to maintain international order so as to maximize the profitability of U.S. capital. This possible endogeneity of military spending calls many empirical analyses that treat military spending as exogenous into question. Also see Garfinkel (1990a), who uses a game-theoretic model to show how military spending can be driven by aggregate economic activity through the government's motive to prevent other nations from extracting its citizens' resources. 
It should be noted that a permanent decline in measured output, triggered by the impact of reduced military spending (and reduced taxes) on leisure, does not necessarily reflect a deterioration in social welfare. Because leisure has value, welfare could increase even if consumption did not. Further, the theory described above suggests that, although individuals would work less, they might actually consume more nondefense private goods because their disposable income has increased their tax liabilities have declined). On net, their welfare would have increased as long as this new outcome were chosen voluntarily. ${ }^{2 z}$

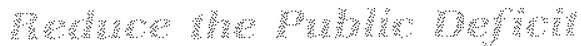

Some analysts, who view large public deficits as harmful to the economy, have argued that the government should use the peace savings to reduce the public deficit. ${ }^{23}$ In particular, the large deficits (public dissavings) of the past decade are thought to have caused a decline in total national savings-that is, the sum of private and public savings. Since a decline in total savings decreases the residual supply of credit available to private borrowers, large public deficits are considered by many to have pushed up expected real interest rates (interest rates adjusted for expected inflation). ${ }^{24}$ Thus, using the dividend to reduce the public deficit would decrease expected real interest rates and thereby stimulate both investment activity and the production of goods, such as exports and new homes, whose sales are sensitive to movements in interest rates.

Although the U.S. savings rate appears to have declined in recent years, how much of this decline can be blamed on large public deficits is unclear. ${ }^{25}$ The argument that public deficits influence the national savings rate is based on a number of potentially questionable assumptions. One is that individuals do not view tax cuts that increase public borrowing (holding the level of government spending constant) as increasing their future tax liabilities. Instead, individuals feel wealthier and increase their consumption in response to such tax cuts. Although they also might respond by increasing their savings, the increase in private savings is assumed to be insufficient to keep total savings from falling. In this view, for a given level of government expenditures, public deficits decrease total savings and increase aggregate demand. ${ }^{26}$

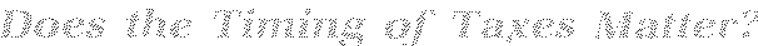

Other analysts argue that individuals believe reductions in current taxes associated with additions to public debt must be financed eventually with additional future taxes. In light of the increase in their future tax liabilities, individuals increase their savings. Conversely, they respond to a decrease in the public deficit, for a given level of government expenditures, by decreasing their savings. In either case, consumption is unaffected.

In this view, often referred to as the "Ricardian" view, individuals behave as if a decrease in the public deficit results in an equal decrease in the present discounted value of their future tax liabilities. This argument builds on the assumption that public debt will be retired eventually out of future taxes. If this view is valid, private and public savings for a given level of government expenditures should be perfectly negatively correlated, while total sav. ings should be unrelated to public savings. ${ }^{27}$

${ }^{22} \mathrm{As}$ discussed below, however, labor and capital resources could be left involuntarily idle temporarily as the economy adjusts to the reduced military demand.

23See, tor example, Schultze (1990). Also, see Chrystal and Thornton (1988) for a related discussion of the effects of deficit spending.

${ }^{24}$ Indeed, this effect on interest rates is thought to be the mechanism through which military spending has crowdedout investment. By enhancing the productivity of private capital, however, military spending could have had a "crowding-in" effect that would have offset its crowdingout effect. But Aschauer $(1989 \mathrm{a}, \mathrm{b})$ presents evidence that does not support the notion that additions to the stock of military capital add to the productivity of private capital. Moreover, the references cited in footnotes 14 and 16 provide evidence that military spending does not crowd out private investment.

${ }^{25}$ Schultze (1990) estimates that national savings as a percentage of national income (i.e, net national product) has fallen from an average of 8 percent during the three

decades before 1980 to 3.3 percent during the first three quarters of 1989 . Some analysts, however, question the notion that savings is too low in the United States; their skepticism is based on problems with the conventional measurements of savings. Cullison (1990) provides a useful survey of this literature.

26 See Thornton (1990) for a theorelical discussion of the link between total national savings and public deficits.

${ }^{27} \mathrm{Against}$ this Ricardian view, one might argue that deficits could be financed either through increased seigniorage or income taxes in future generations. In either case, the "burden" of the current deficit could be shifted and budget deficits, holding government expenditures fixed, could affect economic activity. See Barro (1989) for a brief discussion of the empirical evidence on the effects of budget deficits. While recognizing the problems associated with testing the Ricardian proposition, Barro argues that the existing evidence lends more support to the Ricardian view than to the alternative view (p. 52). 
To be sure, using part of the annual dividend to reduce the public deficit could increase total investment and total consumption. According to the Ricardian view, however, the amounts of these increases do not depend on whether taxes are cut or the deficit is reduced. A cut in the deficit reduces future tax liabilities, but the timing of the tax cuts does not matter.

Because of the distorting nature of the income tax system, however, the equivalence between taxes and debt creation implied by the Ricardian view would be, at best, a rough approximation. Economic theory predicts that proportional income taxation distorts individuals' decisions about consumption and labor supply. These distortions are costly and, other things being equal, the severity of the distortion increases as the tax rate increases. Consequently if the federal government wants to minimize the costs associated with these distortions, given the path of future government expenditures, it should smooth income taxes over time ${ }^{28}$ This modified version of the Ricardian view suggests that tax reductions, rather than deficit reductions, would be a preferable use for the peace dividend. ${ }^{29}$

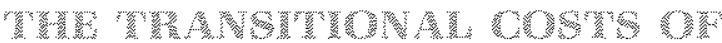

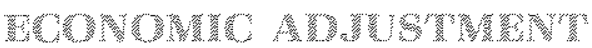

In thinking about how the savings from reduced military spending could be used, it is important to consider how the economy adjusts to unanticipated changes in resource uses. Reduced military spending will produce a negative shortrun effect on production, as labor and capital resources are shifted from military to civilian uses. During the transition period, some resources will be unemployed or underemployed.

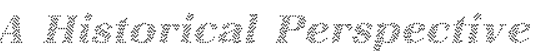

Previous disarmaments have been associated with sizable reductions in economic activity. ${ }^{30}$

285ee Barro (1979). Also see Garfinket (1990b) for an exten sion of this theory to include conscription as an additionat tool for financing public expenditures to avoid the distortions of income taxes, particularly during periods of severe military needs.

29 In this view, deficits are necessary to smooth out the distortionary effects associated with taxes. Hence, a temporary increase in government spending should be financed with debt and a temporary decrease in government spending should result in a budget surplus; this tax-smoothing view of debt creation predicts that deficits are temporary phenomena. Although historical evidence supports this
From the first quarter of 1945 to the first quar. ter of 1946 (peak to trough), for example, nominal GNP fell at a seasonally adjusted annualized rate of $\$ 22.8$ bilion or 10.3 percent. These numbers understate the magnitude of the decline in output as, during this period, there was a considerable acceleration in inflation. ${ }^{31}$ In real terms, GNP fell 18 percent over this period, and it was not until the third quarter of 1952 that the level of real GNP had fully recovered. Although this decline in real GNP is large, it is an overstatement of the drop in national welfare. While the level of employment fell substantially, the unemployment rate rose very little. Instead, a substantial number of workers, particularly women, voluntarily withdrew from the labor force.

The transition to peacetime after WWI was facilitated, in part, by government policies. Tax reductions and transfer payments (unemployment and veteran benefits) left disposable (net of taxes) income nearly unaffected by the massive reduction in military spending. Thus, demand for consumption goods rose to offset partially the decline in military demand.

The sharp decline in military spending that followed the end of the Korean War was associated with a mild recession. From the second quarter of 1953 to the second quarter of 1954 (peak to trough), real GNP fell 3.2 percent. Declines in defense spending and other federal government expenditures, combined with inventory decumulations, were the driving forces here. By the first quarter of 1955, however, real GNP had climbed well above its previous peak.

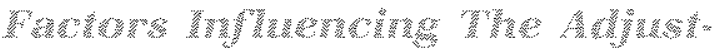

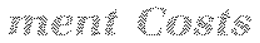

The aggregate adjustment cost for any reduction in military spending can be measured by the real value of resources (labor and capital) left idle involuntarily during the transition. For a given cut in defense spending, the magnitude positive theory of debt creation-..see Barro (1979), for example-it is unclear whether the current deficit is only a temporary phenomenon. Indeed, the magnitude and persistence of the peacetime deficits during the 1980 s are unprecedented in U.S. history.

3aSee Bolton (1966) and references cited therein for a mofe detailed examination of these periods of disarmament. Much of the discussion here draws from this work. Data are taken from Balke and Gordon (1986).

${ }^{3} \mathrm{Th}$ is acceleration was driven, in part, by the removal of price controls in 1946. 
of these costs depends on the speed with which labor and capital resources can be transformed to meet new demands.

The speed of resource transformation, in turn, depends on the degree of specialization of resources used in the military sector. This specialization has two dimensions. First, certain industries, occupations and firms are highly dependent on military demand. Second, military production is highly concentrated in several regions of the United States. Such specialization will slow the adjustment process.

A given reduction in military demand now might generate relatively greater adjustment costs than those associated with large-scale disarmaments following wartime periods. During wartime periods, resources normally used to produce nondefense goods are mobilized quickly and, presumably, on a temporary basis; after the war, resources are rechanneled easily into their original civilian productive activities. In contrast, during peacetime defense firms and their employees expect that demand for their product is essentially permanent. To the extent that these firms and employees have a comparative advantage in the production of defense goods, they are less likely either to diversify their operations into civilian markets or be able to do so in the event of an unanticipated permanent reduction in military spending. ${ }^{32}$

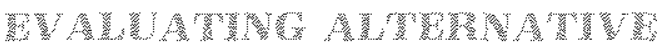

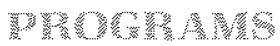

To evaluate society's options for using the savings from reduced military spending, we must address two related economic issues. The first issue, already discussed, concerns what are the best uses of the dividend or the new "highestvalued" uses of the resources previously used in the military (presumably their previous highestvalued uses). The second issue concerns how to rechannel resources efficiently from their military uses to their new highest-valued uses.

${ }^{32}$ In contrast, one might believe that defense contractors, having learned from past experience with sharp declines in military demand, would have diversified their operations to exploit commercial opportunities. While such diversifica tion would provide insurance against large losses to these firms and their employees in the event of an unexpected decline in military demand, past efforts in this direction have not been particularly successful. See Weidenbaum (1973) and Ellis and Schine (1990).

33Representative Boxer's proposal (HR5327) is similar; however, it would penalize defense contractors who close
Some people have advocated establishing public programs-for example, training programs-to lessen the costs of adjustment borne solely by those closely linked to the military sector. A bill introduced recently by Senator Pell (S.2097), for example, seeks to establish a program through which grants would be made to assist state and local governments in developing economic adjustment plans-for example, job retraining and finding alternative uses for defense facilities. These grants would be funded, in part, from the savings from reduced military spending. ${ }^{33}$ Another bill introduced by Senator Coats (S.2682) is intended to aid defense contractors in diversifying their operations into nondefense markets. Through tax incentives, this bill would encourage defense contractors and their employees to adopt employee stock ownership plans (ESOPs) to finance the corporate restructuring necessary to adjust to the reduction in military demand.

These programs are aimed at distributing the adjustment costs and the benefits of reduced military spending equitably; however, they are unlikely to effect an efficient reallocation of resources. ${ }^{34}$ Consider, for example, a program that increases public nondefense expenditures on goods that are most easily produced by the capital and labor resources originally employed for the production of defense goods. While this program might well limit the adverse impact of reduced military spending otherwise borne by those firms and individuals highly dependent on military demand, it is clearly inefficient from the nation's point of view. Unless increased spending on these other goods were deemed desirable on a permanent basis, this policy would not provide firms and individuals with the incentives to channel their resources to new higher-valued uses. Instead, it would merely prolong the process of adjustment and delay the realization of the full benefits from a permanent reduction in military spending.

Nevertheless, the redistributive effects of reduced military spending should not be

their firms uniess a contract has been canceled. The states of Washington and California already have initiated adjustment plans. See Ellis and Schine (1990).

${ }^{34}$ Although the evidence on the effectiveness of manpower programs (for example, the Manpower Development and Training Act) is mixed, some studies find that manpower policies have been successful in raising the earnings of training program participants. See, for example, Ashenfelter (1978). 
dismissed as unimportant or irrelevant in choosing how the peace dividend ultimately will be used. The question of who reaps the gains and who bears the costs of an unanticipated reduction in military spending is an important aspect of the problem and will play an important role in the solution.

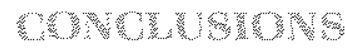

This article has examined some possible effects of a permanent reduction in military spending. In principle, the present discounted value of the implied dividends from such a reduction, in terms of increased consumption and investment opportunities, could be substantial. Through increased private and public investment, reduced military spending implies greater economic growth and, hence, greater consumption and investment opportunities in the future. The important economic questions are, How can these resources be reallocated efficiently to nonmilitary uses? and, How can we identify what these uses should be? This article has introduced and discussed the economic issues that must be addressed in answering these questions; much further analysis and discussion will clearly be needed before these questions can be answered adequately.

Of course, given the recent course of events in the Middle East, the reduction in military spending in the near future might not be large enough to generate any sizable dividend. Thus, debate over whether the savings from reduced military spending should be used to reduce the public deficit, redistributed to taxpayers through tax cuts or be used to rebuild the infrastructure might seem premature. Because many communities, firms and individuals are affected by even small reductions in military spending, however, the "micro" costs of these adjustments will not be ignored in the political decision-making process.

But temporary transitional costs do not justify abandoning the effort to reduce the amount of resources allocated to military spending. Moreover, the Middle East situation is not a permanent obstacle to realize a large dividend in the future. While cuts in defense spending are not expected to be particularly large now, a resolution of the Middle East conflict will permit a much larger dividend in the future.

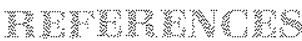

Adams, Gordon, and David Gold. Defense Spending and the Economy: Does the Defense Dollar Make a Difference? (Washington, D.C.: Defense Budget Project at the Center on Budget and Policy Priorities, July 1987).

Aschauer, David. "Does Public Capital Crowd Out Private Capital?" Journal of Monetary Economics (September 1989a), pp. 171-88.

"Is Public Expenditure Productive?" Journal of

Monetary Economics (March 1989b), pp. 177-200.

Ashenfelter, Orley. "Estimating the Effect of Training Programs on Earnings,"Review of Economics and Statistics (February 1978), pp. 47-57.

Balke, Nathan S. and Robert J. Gordon. "Historical Data," in Robert J. Gordon, ed., The American Business Cycle: Continuity and Change (Chicago: The University of Chicago Press, 1986), pp. 781-850.

Barro, Robert J. "The Ricardian Approach to Budget Deficits:" Journal of Economic Perspectives (Spring 1989), pp. $37-54$.

"Output Effects of Government Purchases:" Journal of Political Economy (December 1981), pp. 1086-121.

"On the Determination of the Public Debt," Journal of Political Economy (October 1979), pp. 940-71.

Bolton, Roger E. "Defense Spending: Burden or Prop?" in R.E. Bolton, ed., Defense and Disarmament (Prentice-Hall, Inc., 1966), pp. 1 -53.

Boulding, Kenneth E. "The Impact of the Defense Industry on the Structure of the American Economy, in Bernard Udis, ed. The Economic Consequences of Reduced Military Spending (Toronto: D.C. Heath and Company, 1973), pp. 225-52.

Browne, Lynn E. "Defense Spending and High Technołogy Development: National and State Issues," New England Economic Review, Federal Reserve Bank of Boston (September/October 1988), pp. 3-22.

Chrystal, K. Alec, and Daniel L. Thornton. "The Macroeconomic Effects of Deficit Spending: A Review;" this Review (November/December 1988), pp. 48-60.

Cullison, William E. 'Is Saving Too Low in the United States?" Federal Reserve Bank of Richmond Economic Review (May/June 1990), pp. 20-35.

Dowd, Maureen. "Bush Says Military Can Be Cut $25 \%$ in 5 Years," New York Times, August 3, 1990.

Du Boff, Pichard B. "What Military Spending Really Costs", Challenge (September/October 1989), pp. 4-10.

Dumas, Lloyd d. "National Security and Economic Delusion," Challenge (March/April 1987), pp. 28-33.

Dunne, Paul, and Ron Smith. "Military Expenditure and Unemployment in the OECD," Defence Economics: The Political Economy of Defence, Disarmament and Peace, Vol. 1, No. 1 (1990), pp. 57-74.

Edelstein, Michael. "What Price Cold War: Military Expenditures and Private Investment in the U.S., 1890-1980," mimeo (January 1989).

Ellis, James E., and Eric Schine. "Who Pays For Peace?" Business Week (July 2, 1990). pp. 64-70.

Garfinkel, Michelle R. "Arming as a Strategic Investment in a Cooperative Equilibrium," American Economic Review (March 1990a), pp. 50-68.

"The Role of the Military Draft in Optimal Fiscal Policy," Southern Economic Journal (January 1990b), pp. 718-31. 
Gold, David. The Impact of Defense Spending on Investment, Productivity and Economic Growth (Washington, D.C.: Defense Budget Project at the Center on Budget and Policy Priorities, February 1990).

Melman, Seymour. "Economic Consequences of the Arms Race: The Second-Rate Economy," American Economic Review (May 1988), pp. 55-59.

"Peace Dividend or Peace Recession?" The Economist (April 7, 1990), pp. 31-32.

Pennar, Karen, and Michael J. Mandel. "The Peace Economy: How Defense Cuts Will Fuel America's LongTerm Prosperty," Business Week (December 11, 1989), pp. 50-55.

Riddell, Tom. "U.S. Military Power, the Terms of Trade, and the Proft Rate," American Economic Review (May 1988), pp. 60-65.

Schultze, Charles L. "Using the Peace Dividend to Increase Saving," Challenge (March/April 1990), pp. 11-17.

Smith, Ron P. "Military Expenditure and Capitalism," Cambridge Journal of Economics (March 1977), pp. 61-76.
"Mititary Expenditure and Capitalism: A Reply," Cambridge Journal of Economics (September 1978), pp. 299-304.

Stevenson, Richard W. "Suppliers Brace for Arms Cuts;" New York Times, June 18, 1990.

Thornton, Daniel L. "Do Government Deficits Matter?" this Review (September/October 1990), pp. 25-39.

Uchitelle, Louis. "Economy Expected to Absorb Effects of Military Cuts," New York Times (April 15, 1990).

U.S. Congressional Budget Office. Defense Spending and the Economy (Government Printing Office, February 1983).

Budgetary and Miltary Effects of a Treaty Limiting Conventional Forces in Europe, Special Study (January 1990).

Weidenbaum, Muray. "Defense Outlays Have Declining Impact on Economy," Christian Science Monitor, February 7 , 1990

"Industrial Adjustments to Military Expenditure Shifts and Cutbacks," in Bernard Uris, ed., The Economic Consequences of Reduced Military Spending (Toronto: DC. Heath and Company, 1973), pp. 253-87. 